\title{
Eugen Berthold, Eugen, posléze Bert a nakonec Bertolt Brecht
}

\author{
Martina Musilová
}

\begin{abstract}
PARKER, Stephen. Bertolt Brecht. Praha: Nakladatelství Akademie múzických umění, 2019. 714 s. Přeložili Ladislav Köppl, Kateřina Klabanová a Věra Kloudivá (verše), s využitím překladů Ludvíka Kundery a Rudolfa Vápeníka.
\end{abstract}

V roce 2014 vydal britský germanista, profesor University of Manchester, Stephen Parker rozsáhlou biografii nejvýznamnějšího dramatika a divadelního reformátora německojazyčného divadla 20. století Bertolta Brechta (Bertolt Brecht. A Literary Life, Bloomsbury, 2014). Je zásluhou pražského Nakladatelství Akademie múzických umění, že překlad této monumentální studie o více než šesti stech stranách je od loňského roku přístupný i českému čtenáři. Německé vydání vyšlo o rok dříve pod názvem Bertolt Brecht. Eine Biographie (Suhrkamp Verlag AG, 2018).

Brechtův životopis česká teatrologie postrádala. S Parkerovou biografií získává ale mnohem víc, nebot autor se snaží zachytit vedle Brechtova osobního života a tvưrčího směřování i politický kontext a komplikované dobové souvislosti. Čtenár̆ je doslova zaplaven detaily, které spoluurčovaly Brechtovo životní putování. Příběh je to vrstevnatý, komplikovaný a nejednoznačný. S nadsázkou se dá říci, že jej nelze zachytit aristotelovskou formou dramatu, které má začátek, střed a konec. Aby dosáhl patřičné „epické šíře“, musel Parker prostudovat neuvěřitelné množství archivního materiálu, dopisů či Brechtových deníkových záznamů. Již tak obsáhlou brechtovskou literaturu obohacuje Parkerův životopis o pečlivé sledování Brechtova celoživotně neuspokojivého zdravotního stavu, vhled do životních příběhů Brechtových spolupracovnic, respektive milenek/ manželek (E. Hauptmannové, M. Steffinové, R. Berlauové, H. Weigelové a dalších a dalších a dalších), a o plastické zachycení úsilí, s jakým Brecht a Weigelová zakládali Berliner Ensemble ve městě pod správou Sovětů.

Kvalita každé biografie se prověřuje tím, jak dalece překračuje předmět svého zájmu - v tomto případě život „nebohého BB“. A v tomto smyslu přináší plody opravdu nebývale bohaté. Mnohé Brechtovy životní epizody můžou teatrologové z postkomunistického východního bloku vnímat modelově a nechat se tak inspirovat pro výzkum vlastní levicové avantgardy. Některé souvislosti Parker pojmenovává explicitně. Např. Brechtovo protestantské rodinné zázemí, které měl shodné s druhým tvůrcem politického a epického divadla Erwinem Piscatorem. Z luteránského protestantismu pak lze odečítat Brechtovu provokativní bojovnost a asketismus, stejně jako snahu se z nich vymanit v hedonismu Baala a laskavosti mudrce Keunera. Co Parker explicitně nepojmenovává, lze ale přesto z životopisu vyčíst díky pečlivému zachycení tvůrčích podnětů a opakujících se motivů Brechtova života. Tím je např. Brechtovo hledání a podněcování 
„revoluční energie“ a „revolučního náboje“. Brecht, stejně jako celá generace levicových a komunistických avantgardních tvůrců 20. a 30. let minulého století, čerpal svou vizi společenské proměny nikoli ze společenského uspořádání v nově vzniklém Sovětském svazu, ale z revoluční energie, která vznik SSSR umožnila. Vycházel ze zkušenosti spartakovského povstání a Bavorské republiky rad v roce 1919, včetně jejich selhání. Tento životní zážitek se jeví jako základní podnět pro jeho příklon k marxismu v mládí i ochotu podřizovat se moskevské stranické linii v dobách temnějších - např. v době moskevských procesů a čistek, které se časově kryjí s jeho skandinávským exilem, - nebo v době budování socialismu v poválečném Německu. Brecht postupně cítil, jak paranoidní Stalinův systém znemožňuje prosazení tohoto revolučního náboje v Rusku i celé evropské společnosti. Přesto byl ochotný disciplinovaně podřizovat svou tvorbu politickým rozhodnutím, nadto z vlastního přesvědčení. Naděje na násilný revoluční obrat jej neopustila do konce života.

Nicméně Brecht nebyl žádný Trockij, ač byl z trockismu Moskvou podezírán. Byl stratégem a strategické kličkování, jak ukazuje Parker, bylo jeho konstantním povahovým rysem - v dětství, kdy si hrál na Napoleona či Friedricha Velikého, v pubertě, kdy nadbíhal děvčatům, v dospělosti, kdy nadbíhal nakladatelům. Projevuje se i v jeho boji za „tu věc“. Lze jen těžko posoudit, co u Brechta dominuje a určuje jeho kroky, zda jeho povaha, Leninův spis Dětská nemoc „levičáctvi“ v komunismu (1920), Konfuciovo učení, Stalinův 6. sjezd Kominterny nebo taoistická doktrína wu-wej. Všechny tyto vlivy se nerozlučně splétají v exemplárním Brechtově manifestu Pět potiži při psani pravdy z roku 1934.
Strategické kličkování se pojí s ještě jedním výrazným povahovým rysem, který je snad nejvíce opředen brechtovskými mýty (a drby). Díky Parkerově pečlivosti při zpracování archivních materiálů a důslednému ukazování karet, se kterými Brecht v konkrétních situacích hrál, je nyní možné nejeden z těchto mýtických závojíčků strhnout. Brecht při svém rozehrávání partií na vícero stranách záměrně vytvářel svou image (hedonisty Baala, machistického drsňáka se sloní kůží, disciplinovaného pracovníka revoluce, asketického pana Keunera, laskavého učence, marxisty či majitele konta ve švýcarské bance). S proměnami tváří Brecht postupně proměňoval i své jméno, což dodnes dělá problémy editorům (a studentům). Mnohost Brechtových tváří se zrcadlí i v mnohosti Brechtových partnerek. Jistě, choval se k nim šovinisticky a koloniálně a neuměl je opustit ani poté, co vztah vyhořel a on jim neměl co nabídnout. Ale nejsou tyto osobnostní rozpory autentickým odrazem Brechtova dramatického talentu? Byl by člověk vnitřně „konzistentní" schopen napsat Galy Gaye, Mauera, Šen Te/Šuej Tu či Puntilu? A není schopnost vytvořit image, tj. svého druhu iluzi, předpokladem vytvoření efektu jejího zcizení?

Nepolapitelnost, protikladnost a nespoutanost Brechtovy povahy zachycuje Parker již v době jeho dospívání v provinčním Aušpurku. Brechtova osobnost vždy magnetizovala. Jedny neodolatelně přitahovala, druhé doslova odpuzovala. Vždy měl ale Brecht úžasnou schopnost vytvořit souručenství spolupracovníků. Fascinace Brechtem, či jeho prríkré odsuzování, jsou zpravidla největší slabinou odborných i popularizačních textů o tomto německém divadelníkovi. Zda se Parkerovi podařilo udržet si kýžený odstup 
díky britské věcnosti a ne-ideologičnosti či dvougeneračnímu přeryvu, nejsem schopná posoudit. Jisté je, že se mu podařilo nepodlehnout Brechtově uhrančivosti díky důslednému sledování svého autorského záměru, jímž je zmapování tvưrčí cesty, Brechtových hledání a objevování uměleckého výrazu. Parker citlivě ukazuje, že neexistuje hranice, která by určila, kde končí člověk a kde začíná báseň. Přiznám se, že tuto Parkerovu schopnost oceňuji nejvíce. A pro českého čtenáře by mohla být nejpoučnější.

Germanistu Parkerovi se daří více při interpretacích Brechtových textů. Zjevně není dostatečně obeznámen $\mathrm{s}$ výboji ruské a sovětské divadelní avantgardy (Mejerchold, Ejzenštejn, Šklovskij), když přičítá Brechtovi její inovace. Kapitoly knihy jsou rozvrženy v časových úsecích (napřr. 1903-
1912, 1922-1924), uvnitř kapitol ale musí čtenář mnohdy dohledávat či domýšlet konkrétní rok, ve kterém se popisovaná událost odehrála. Ocenění si žádá překlad Ladislava Köppla, jenž si uchoval svěžest a poutavost Parkerova stylu, a odborná redakce publikace (P. Christov). Snad jen u Žebrácké opery mohly být uvedeny další české varianty, pod kterými byla Die Dreigroschenoper $\mathrm{v}$ češtině uváděna (Tř́grošová, Krejcarová).

Parkerův životopis přináší obraz provokativně komplikovaného tvůrce. Už to samo je pro českou kulturu, cyklicky upadající do biedermeierovského poklidu uspávajícího čilého ducha, hodnotou. Snad třaskavý příběh alespoň trochu českými čtenáři zatřese. A snad v něm naleznou čtenáři i mnohé poučení, aby nemuseli opakovat chyby „nebohého BB“. 